\title{
Identifying Motivational Factors of Pre-service EFL Teachers
}

\author{
Ebru A. Damar \\ Faculty of Education, \\ Uludag University, Bursa
}

Doi: 10.2478/ajis-2018-0015

\begin{abstract}
For over sixty years what motivates individuals to become teachers and how they perceive teaching as a career have been investigated through a growing body of research. The underlying reasons for the research are mostly the problems of teacher shortages and teacher quality. To maintain informed and intelligent generations, teacher quality and teaching cover an important ground in the development of many countries all around the world. The issue of teacher shortages and teacher quality not only differs from one country to another but also from one field to another. In this regard, English language teaching (ELT) is one of the fields that experience teacher shortage and teacher quality issues in Turkey than other teaching fields. Therefore, this study aimed to explore the motivations of pre-service EFL teachers for choosing 'teaching as a profession and their perceptions about teaching career'. A total of 210 preservice EFL (English as a Foreign Language) teachers voluntarily participated in the study. The data was gathered by utilizing a motivation scale. The results revealed that prior experiences as a learner, social utility values were the most significant motivation factors for teacher trainees. The findings were discussed in relation to language teacher education.
\end{abstract}

Keywords: teacher motivation, language teacher education, teacher trainees, EFL

\section{Introduction}

In Dörnyei and Ushido (2011), it is stated that the level of motivation is one of the crucial elements that affect learners' motivation in classroom and "if a teacher motivated to teach, there is a good chance that his or her students will be motivated to learn" (p.158). Much attention has been paid to learner motivation, however, that of teachers has not yet been widely investigated. The motivational disposition of teacher trainees and their aspirations to become a teacher, on the other hand, seemed to be even more neglected (Watt and Richardson, 2007; Watt and Richardson, 2008; Salı, 2013; Bier, 2014).

Teacher shortages, severe teacher attrition, and growing need for quality teaching has made the related research inevitable. As the Organization for Economic Cooperation and Development (OECD) report indicated, teachers' work load has become more demanding along with the diversity in students' background, high expectations of schools and students on teacher competencies (Watt, Richardson and Klusman, 2012). There is also an understanding that achievement in a country's education system mostly depends on the quality of their teachers. Ensuring this quality has only been provided through quality teacher training programmes and motivated teacher candidates. Therefore, it is highly needed to understand the underlying reasons for teaching choice, their longterm perspectives about the profession and their professional plans.

\subsection{Research on Language Teacher Motivation}

As Ushido (2009) points out that motivation is not an isolated characteristic, but emerges from the 
interaction between "human intentionality and social structure" (p.221). In line with this statement, the relevant literature clearly shows that language teaching has both cognitive and social elements. While exploring language teacher motivation, both the cognition and affective factors, and social influences should not separately be investigated.

Most of the studies held in teacher education field either draw a general framework of inservice teacher motivation or focus on pre-service teacher motivation in general not on individual fields. Moreover, the studies exploring pre-service language teacher motivation shed light on either the factors influencing teaching motivation or not using well defined constructs most of the time. (Bier, 2014; Suppiah, Hari, Sunder and Velayudhan, 2012; Richardson and Watt, 2006; Bosnyák and Gáncs, 2012; Brookhart and Freeman, 2012). They do fail to investigate cognitive, "inner" and social, "outer" influences together. Accordingly Watt and Richardson (2007) developed a scale based on the expectancy-value theory of achievement motivation (Wigfield \& Eccles, 2000). The theory suggests well-defined constructs such as subjective task value, perceived task difficulty and beliefs about ability. It is grounded on the belief that, as human beings, we are only motivated to do something if we have expectancy for success. In this regard, the Factors Influencing Teaching Choice (FIT-Choice) scale maintained a reliable guide to investigate the reason why people choose teaching as a career.

\subsection{Teaching Motivation/Choice in Turkey}

In most of OECD countries, educational authorities and institutions seek quality teaching staff and do their best to understand the motivational factors leading teacher candidates to choose teaching as a career and sustain them in the profession. Turkey, of which $25.6 \%$ of population is under the age of 14 , is in a very different situation (Turkish Statistics Institution, 2009). There is a really oversupply of teacher education programme graduates in most of the fields and they are in a competition for teacher positions in both government and private sector. The demographic situation, on the other hand, requires a great demand for qualified teachers to educate the young population. Like many other countries, Turkey also need more teachers in the fields of preschool, language teaching and special education domains (Kılınç, Watt and Richardson, 2012; Eren and Tezel, 2010, Salı, 2013). The growing teacher shortages in the field of English Language Teacher (ELT) education makes the domain an important context to be investigated. Thus the study aimed to explore the factors influencing teaching choice/motivation of pre-service EFL teachers by especially focusing on constructs ranging from ability, intrinsic career value, fallback career, personal utility, job transferability to social status, social influences and salary.

\section{Method}

\subsection{Language Teacher Education in Turkey}

Teacher candidates have been trained in Education Faculties in four-year programmes since the foundation of the Higher Education Council (HEC) in 1981. After restructuring the institutions as education faculties, regular revisions are made in teacher education curricula in order to be able to integrate the most recent developments (Batuhan, 2007). English language teacher education is no exception. Following the latest revision made in 2007, pre-service EFL teachers started to take courses that develop their language proficiency such as Contextual Grammar, Advanced Reading and Writing Skills, Listening and Pronunciaton. Prospective English teachers also take methodological courses both in their own field such as Methodology I and II, Teaching English to young Learners, Approaches in English Language Teaching and Material Evaluation and Development in English Language and also courses in the field of education such as Introduction to Educational Sciences, Educational Psychology, and School Administration. In their final year, they also take School Experience and Teaching Practicum courses where they spend most of the time in public and private schools experiencing actual teaching. 


\subsection{Participants}

The participants of the present study were pre-service EFL teacher candidates enrolled in four-year teacher education programme in one of the large government universities in Turkey $(\mathrm{N}=210) .210$ questionnaires were distributed to all first year pre-service EFL teachers in ELT department at the sample university. With a $65.23 \%$ response rate, 137 questionnaires were returned. Of 137 preservice teachers, $78,8 \%$ are female and 21,2 are male. The participants ranged in age from 18 to 31 years. The household size ranged between 2 and 9 people. Annual income was selected by the participants from four bands in increments of 15,000 Turkish Liras (TL) $(0-15,000$ TL to 120,001+ TL the highest); 60 of 137 respondents (43.8\%) selected very low level income option, 47 (34.3) selected low, 17(12.4\%) average, $9(6.6 \%)$ selected high income level as their families' income level. ( 1 US dollar currently equals to $3.75 \mathrm{TL}$ ). Among the parents, the fathers of the participants had higher educational background than their mothers: $35(25.5 \%)$ of fathers were graduated from primary school, $29(21.2 \%)$ secondary school, $37(27 \%)$ from high school, $32(23.4 \%)$ from university, $2(1.4 \%)$ had a Master's degree and $1(0.7 \%)$ a PhD degree. As for mothers, $70(51.1 \%)$ graduated from primary school, $27(19.7 \%)$ secondary school, $23(16.8 \%)$ from high school, 16 $(11.7 \%)$ from university and $1(0.7 \%)$ had an MA degree. Regarding parents' professions, only 11 $(8 \%)$ of the fathers and $5(3.6 \%)$ of the mothers were teachers. When the participants asked when they decided to choose teaching as a profession, $28(20.4 \%)$ of them stated that they made the decision during the university entrance exam, 69 (50.4\%) during high school years and $39(28.5 \%)$ declared primary school years as the timing of the decision to teach.

\subsection{Instruments}

The Turkish (the participants' first language) version of The FIT-Choice/motivation scale (Kılınç et al., 2012) was adapted to gather the data. The scale consists of three parts consisting several items under some subscales describing different motivational factors. These are the "intrinsic values" (pre-service' teachers' interest in and desire to teach), "personal utility values" (reasons related to job security, time for family, job transferability), "social utility values" (pre-service' teachers' desire to shape future of children/adolescents, make social contribution, enhance social equity, work with children/adolescents), "self perceptions of their abilities"( pre-service' teachers' perceptions of their teaching abilities), "fallback career choice" (pre-service' teachers' selection of teaching as a career because they have not been accepted into their first choices), "social influences" (teaching and learning experiences, peers' or parents' influence on their decisions) subscales (Watt and Richardson, 2007). The reliability and validity test was employed for each section of the scale. The reliability test results for each part are as follows: Part A has .769, Part B .934 and Part C .761 Cronbach alpha values ( see Table 1).

Table 1. Reliability Statistics

\begin{tabular}{ccccccc}
\hline Year & \multicolumn{2}{c}{ Motivation Scale Part A } & \multicolumn{2}{c}{ Motivation Scale Part B } & \multicolumn{2}{c}{ Motivation Scale Part C } \\
\hline & Cronbach's Alpha & N of Items & Cronbach's Alpha & N of Items & Cronbach's Alpha & N of Items \\
\hline 1st year & .769 & 11 & .934 & 40 & .761 & 16 \\
\hline
\end{tabular}

After analyzing the data driven from the scale, a follow-up semi-structured interview were held with 32 pre-service EFL teachers to be able to clarify some points not answered in the scale and elaborate on the issue. As for the data analysis process, both qualitative and quantitative methods were employed. 


\section{Results and Discussion}

\subsection{Reasons for Choosing Teaching as a Career}

The data analysis show that pre-service EFL teachers had a higher level of motivation towards teaching profession in the total score $(M=4.73)$. The mean ratings of each item indicate that social utility values (shaping the future of children/adolescents, enhance social equity, making social contribution) have the highest score $(M=4.82)$. It is followed by work with children/adolescents $(M=4.68)$, job security $(M=4.60)$ and enhancing social equity $(M=4.59)$. During the interviews participants specified that they really love spending time with children and also teach them. Most of them also mentioned that they had had teaching experiences during their secondary and/or high school years while tutoring their classmates and/or relatives. These anecdotal evidences show us that social desire to be accepted and social acknowledgement by their social environment date back to their experiences even as learners.

These results are in line with other research in which Fit-Choice Scale was used (Kılınç, 2012; Topkaya and Uztosun, 2012; Eren and Tezel, 2010). The results are also similar with the results of other studies used different data collection tools. The results of these studies also show that prospective teachers choose teaching as a career with altruistic motivation (Thomson, Turner and Nietfield, 2012; Kyriacou \& Coulthard, 2000; Pop \& Turner, 2009; Salı, 2013). It is also supported with the idea that motivation studies should investigated cognitive (inner) and social (outer) influences together (Ushido, 2009; Bier 2014).

The results of the order of the constructs do not align with the ones conducted in other countries (i.e. America, Avustralia) where intrinsic career value and ability constructs get higher mean scores (Watt and Richardson, 2007; Watt et al., 2012) than that of social utility values as Kılınç (2012) explains different cultures reserve unique structures. Moreover the level of welfare, the policy refinements and demographic status of the countries can affect the career motivations of the individuals in those countries. Why the altruistic reasons, here social utility values, had the high value among the constructs mostly depends on Turkish culture's collectivist nature, that is to say group goals are more important than the individuals' own aims. The interview data also support the findings that social acknowledgements and students' admiration are the most repeated themes by pre-service EFL teachers.

The results also show that the motivational tendencies of the participants who take/attend a professional orientation/guidance course/seminar before university entrance exam are higher than the ones who do not involve any informative occasion about the issue. The need for involving in orientation programs/seminars before career choice was also uttered by some of the participants during the interviews. As Bosnyak and Gancs (2012) also states that along with the factors affecting the intrinsic component of teacher motivation the appropriate training and/or orientation plays an important role as an external influence and shapes pre-service teachers' preconceived beliefs about the teaching profession. Thus, these preparatory training would transform obstacles into opportunities for the sake of adequate career structures.

\section{Conclusion and Implications}

Due to the growing shortage of quality language teachers in Turkey, it is becoming more important to identify what motivates enthusiastic young people to choose language teaching as a profession. To better understand the situation, the present study aimed at gaining insights into the reasons of choosing teaching as a career by pre-service EFL teachers in a public university in Turkey. In overall results, high levels of career motivations are observed. Their being well motivated proposes a usual preliminary for both researchers/academics who develop teacher education programs and the trainers who are actual practitioners in the programs. The varied reasons such as social utility values, viz shaping the future of children/adolescents, enhance social equity, making social contribution, work with children/adolescents, job security and enhancing social equity show forth altruistic reasons play important role in career planning for teacher candidates. These shed some lights to researchers which factors are need to be deeply examined and also what other constructs 
can be developed for examining the career motivations. The last but not the least policy makers should focus on the issue to increase the social status of teaching profession so as to it is preferred by a large audience.

\section{Limitations and Suggestions for Further Research}

The present study was designed as a preliminary step of a research project that will explore preservice language teacher motivation in wider circles, primarily national and then global scope. The results of the small sample size of the study will be in the forefront of the wider projects. Consequently, it means that it cannot be generalized to all country but the results can serve as a preview of first year pre-service EFL teachers' motivational disposition. Longitudinal research might be held with them on their last year at the faculty and/or their first years in the profession to see the motivational changes through retrospection. Additionally case studies, utilizing observations, journals as data collection instruments, might be conducted for deeper insights into career motivations of language teacher candidates.

\section{References}

Batuhan, A. (2007). Turkey country case study. Country profile prepared for the education for all global monitoring report. United Nations Educational, Scientific and Cultural Organization.

Bier, A. (2014), "The Motivation of Second/Foreign Language Teachers: A Review of the Literature". in EducazioneLinguistica Language Education, 3, 505-521.

Bosnyák, J. \& Gáncs, N. (2012). The motivational disposition of English language teacher trainees. WoPaLP, 6 , 64-78.

Brookhart, S. M., \& Freeman, D. J. (1992). Characteristics of entering teacher trainees.Review of Educational Research, 62(1), 37-60.

Dörnyei, Z., \& Ushioda, E. (2011). Teaching and Researching Motivation (2nd ed.). Harlow, UK: Longman.

Eren, A., \& Tezel, K.V. (2010). Factors influencing teaching choice, professional plans about teaching, and future time perspective: A meditational analysis. Teaching and Teacher Education, 26,1416-1428.

Kyriacou, C., \& Coulthard, M. (2000). Undergraduates' views of teaching as a career choice. Journal of Education for Teaching, 26, 117-126.

Kılınç, A., Watt H.M.G., \&. Richardson P. W. (2012) Factors Influencing Teaching Choice in Turkey, AsiaPacific Journal of Teacher Education, 40:3, 199-226.

Pop, M., \& Turner, J. E. (2009). To be or not to be.a teacher? Exploring Levels of Commitment Related to perception of Teaching among Students Enrolled in a Teacher Education Program. Teachers and Teaching Theory and Practice, 15(6), 683-700.

Salı, P. (2013). Understanding Motivations to Become Teachers of English: ELT Trainees' Perceptions. Procedia-Social and Behavioral Sciences, 93, 1418-1422.

Suppiah Nachiappan, Hari Krishnan Andi, Sunder Subbramaniam \& Velayudhan P. K. Veeran (2012). Factors that motivates the teacher trainees of teacher training institutions to possess an excellent personality through hermeneutic analysis method. Journal of Educational and Developmental Psychology, 2(2), 97104.

Topkaya, E.Z., \& Uztosun, M.S. (2012). Choosing teaching as a career: Motivations of pre-service English teachers in Turkey. Journal of Language Teaching and Research, 3, 126-134.

Ushioda, E. (2009). "A Person-in-Context Relational View of Emergent Motivation, Self and Identity». In: Dörnyei, Z.; Ushioda, E. (eds.), Motivation, Language Identity and the L2 Self. Bristol (UK): Multilingual Matters, pp. 215-227.

Watt, H. M. G., \& Richardson, P.W. (2007). Motivational factors influencing teaching as a career choice: development and validation of the FIT-choice scale. Journal of Experimental Education, 75(3), 167-202.

Watt, H. M. G., \& Richardson, P.W. (2008). Motivations, perceptions, and aspirations concerning teaching as a career for different types of beginning teachers.Learning and Instruction, 18(5), 408-428.

Wigfield, A., \& Eccles, J. S. (2000). Expectancy-value theory of achievement motivation.Contemporary Educational Psychology, 25, 68-81.

Watt, H. M. G., Richardson, W. P., Klusmann, U., Kunter, M., Beyer, B., Trautwein, U., et al. (2012). Motivations for choosing teaching as a career: An international comparison using the FITChoice scale. Teaching and Teacher Education, 28, 791-805. 